\title{
Interview with Ron Holloway
}

By Felix Neunzerling

Spring 2007 Issue of KINEMA

\section{INTERVIEW WITH RON HOLLOWAY ON OCCASION OF HIS BERLINALE CAMERA AWARD 2007}

ZOOM: Your career as a film journalist is directly connected to international festivals. How long have you been associated with the Berlinale?

My first visit to the Berlinale was in 1965. At the time I will spending a summer at the Cinémathèque Française, "pirating" rare film prints from New York distributors to Henri Langlois for his archive. Langlois gave me a courtesy pass to all Cinémathèque screening. One day, Lotte Eisner at the Cinémathèque suggested that I visit the Berlinale and see what the young German filmmakers were up to. So I took an Air France flight to Tegel, at that time a barn instead of a terminal, and spent a week at the Zoo Palast as an accredited journalist for Film Society Review in New York.

When did you visit the Berlinale together with the "star" of many German movies, Dorothea Moritz?

That was 1968. I was a Rockefeller Fellow with a two-year grant to live and write in Paris. But the Student Revolution - first at Cannes, then at the Sorbonne - drove me out of the city. I met Dorothea that year at the Karlovy Vary film festival, held in June to accommodate Western journalists swarming all over Prague. Of course, Alexander Dubček and "Prague Spring" were the primary reasons, but "Czech New Wave" was just as interesting - Ján Kadár and Elmar Klos's The Shop on Main Street and Jiří Menzel's Closely Watched Trains were recent Oscar winners. Dorothea and I spent a lot of time together at the festival's Forum Roundtable discussions. It was an exciting time. So we agreed to meet again a week later at the Berlinale. We saw Jean-Marie Straub's Chronik der Anna Magdalena Bach (The Chronicle of Anna Magdalena Bach, 1968) and Werner Herzog's Lebenszeichen (Signs of Life, 1968). I remember saying to Dorothea that Lotte Eisner was right. Anyway, to make a long story short, Dorothea and I married in September of 1968.

Is that why you moved to Berlin to work at the Berlinale? Love at first sight!

When Wolf Donner was appointed the new director of the Berlinale in 1976, he asked me to join his selection committee. At that time he was living in Hamburg and writing for Die Zeit. I think he was one of Germany's best film critics. I had just received my Doktor Theologie at the University of Hamburg, when Variety in New York asked if I would be interested to replace the late Hans Höhn as correspondent from Berlin. The offer was too good to pass up: I was given Germany and Eastern Europe as my territory to cover. So when Donner asked if I would join him at the Berlinale as a member of the selection committee, I jumped at the chance and worked as a selector during Donner's three-year tenure at the Berlinale. He also asked me to head the Info Schau, the forerunner of today's Panorama. Dorothea came with me to Berlin. Wolf Donner was pleased, too, because he wanted her to screen films for the new festival sections. For the next 19 years she remained on the Berlinale selection committee for the Children's Film Festival and did the over-talk for young audiences.

Who joined you on the Berlinale selection committee?

It was pretty evenly divided between men and women. Regina Ziegler, Jeanine Mehrapfel, Christel Märker, Michael Weinert, Kraft Wetzel, Wolf Donner, and myself - with Bodo Fründt, Jane Dawson, and Werner Gondolf in the front office. Jane Dawson joined us from London, where she edited the BFI Monthly. Bodo Fründt was, and is, a top journalist on American and European Independent Cinema. Florian Hopf flew in from München to handle chores on a daily Berlinale Journal. Together, under the visionary Wolf Donner, we helped to launch an international film festival with many attractions for the Berlin audience. Of course, there was the International Forum of Young Cinema as well, but this only made it more challenging and rewarding for all. After all, this was the heyday of New German Cinema, a "movement moniker" I coined in Variety to embrace all the creative energy let loose in German cinema at that time.

Is that also when you founded KINO German Film? 
No. That was later, in 1978. To launch my idea for a German Film Tour in the USA, Dorothea and I founded KINO German Film to promote what we consider the best in German cinema. This year's Berlinale issue, KINO 88, is still supported by generous advertisers and the Goethe Institut. I like to think that this example of press independence was one of the reasons why I received the Bundesverdienstkreuz.

Did you have a hand in the 1977 Golden Bear for Larisa Shepitko's Aufstieg - The Ascent? If I did, then I am very proud of having supported that film with all the possibilities at my disposal at that time. While viewing Soviet films in Moscow at Goskino, Wolf Donner and I had to wrestle with Film Minister Filipp Yermash to win his approval for this Berlinale entry. Yermash, of course, wanted us to take a socialist-realist Party film. We won the argument by pointing out that we, too, would have a difficult time at the Berlinale promoting a Russian film in which the German Wehrmacht appeared to be less than human in dealing with partisans in Belorussia. In retrospect, the only dilemma we faced at the festival was a split jury. Rainer Werner Fassbinder and Derek Malcolm, among others, supported the Robert Bresson entry. The tide was turned when I asked Jerry Rappoport, the "Jack Valenti for Eastern Europe," to introduce Larisa Shepitko to Ellen Burstyn. She ended up casting the deciding vote. For Dorothea and myself, it was an exciting Berlinale, perhaps the best in its distinguished history.

When did you interview Sergei Parajanov for your documentary Parajanov, A Requiem? During the Filmfest München in July of 1988, when the Sergei Parajanov Retrospective was programmed by Klaus Eder. Parajanov agreed to an interview on the spot because we had spent time together in Baku the year before, when he was editing Ashik Kerib, his last film. The screenings were filled with Parajanov admirers, although many in the press didn't know what to make of him. So a documentary was planned. The financing came out of own pocket. Kora Zeretelli, Parajanov's close friend, helped with the translation. Parajanov also took an instant liking for Thomas Schwan, our cameraman. Dorothea's presence was another major confidence builder during the shooting. Our nephew, Christoph Sedlag, drove me nightly to the Geyer Lab in München to copy the nineteen excerpts from his films used in the documentary. Everyone lent a hand.

Why did it take so long to release Parajanov, A Requiem?

First of all, because Parajanov and I had agreed that this interview would form the first half of a 90minute documentary. The second half would be made while he was shooting his autobiographical film, to be titled Confession, the following spring in April of 1989.But he could only complete a day of shooting, then was rushed to a hospital to have a lung removed. I visited him at the hospital in Moscow to boost his spirits a bit. Friends arranged for him to see more doctors in Paris. All in vain - he died in 1990. After that setback, it took us four more years to find the financing for the post-production. The German TV stations showed little or no interest - a puzzle to me to this very day, for Parajanov ranks with Eisenstein and Tarkovsky as an outstanding creative master in the history of cinema. It wasn't until Frank Löprich and Katrin Schlösser at Ö-film stepped in to help us complete the film in 1994. Gordian Maugg helped, too, with the post-production, as did our editor Monika Schindler. Indeed, I can't tell you how many people helped in the meanwhile. The reward for this long wait was an invitation to present Parajanov, A Requiem at the Venice festival - followed by invitations to thirty more international film festivals. When Planet TV, the French Documentary Cable Channel, programmed the film, the French press responded enthusiastically, particularly the critic at Le Monde. Currently, Don Krim at Kino International in New York, is distributing DVDs of our documentary.

\section{Any other special memories?}

Just one. When Dorothea and I were invited last summer to attend the Golden Apricot International Film Festival in Yerevan, we had the opportunity to visit the Parajanov Museum. Two floors of collages, painting, art objects of every sort from the life and times of Sergei Parajanov. It takes your breath away. Later, at the Union of Armenian Filmmakers, we were presented with a "Sergei Parajanov Museum Medal" in recognition of our documentary. It was, indeed, a proud moment.

\section{Author Information}


Felix NEUNZERLING is the editor of ZOOM, published by ZOOM Medienfabrik GmbH, Berlin, a public relations and advertising company. 